\title{
In vivo evaluation of Berberis vulgaris extract on acute toxoplasmosis in mice
}

Hossein Mahmoudvand, Amir Tavakoli Kareshk, Amir Keyhani, Naser Zia-Ali , Mohammad Reza Aflatoonian

\begin{abstract}
Since last centuries, herbal medicines have been considered as the main source for prevention and treatment a broad spectrum of illnesses as well as infectious diseases. Here we evaluated the in vivo activity of Berberis vulgaris methanolic root extract against acute toxoplasmosis induced by Toxoplasma gondii, $\mathrm{RH}$ strain. Male NMRI mice orally treated with $B$. vulgaris methanolic extract at the dose of 1 and $2 \mathrm{~g} / \mathrm{kg}$ once a day for 14 days after 24 $\mathrm{h}$ mice were infected intraperitoneally with $10^{4}$ tachyzoites of $T$. gondii, RH strain. The mortality rate in all infected mice and also parasite load were determined to assess the efficacy $B$. vulgaris methanolic extract against acute toxoplasmosis in mice model. The obtained results demonstrated that the mortality rate of
\end{abstract}

infected mice was $100 \%$, in $9^{\text {th }}$ day after orally administration of B. vulgaris at the concentrations of 1 and $2 \mathrm{~g} / \mathrm{kg}$; while all mice in the control group were death in 5th day. Moreover obtained findings revealed that the mean number of tachyzoites was $131 \times 10^{4}$ and $79 \times 10^{4}$ for infected mice treated with B. vulgaris at the concentrations of 1 and $2 \mathrm{~g} / \mathrm{kg}$, respectively, whereas in control group the mean number of tachyzoites was $288 \times 10^{4}$ parasite. The obtained findings demonstrated the potential of $B$. vulgaris as a natural source for the production of new prophylactic agent for use in toxoplasmosis.

Keywords: Toxoplasma gondii; Berberis vulgaris; Prophylactic; In vivo
Hossein Mahmoudvand

Razi Herbal Medicines Research Center, Lorestan University of Medical Sciences, Khorramabad, Iran

Amir Tavakoli Kareshk, Amir Keyhani, Naser Zia-Ali

Research Center for Tropical and Infectious Diseases, Kerman University of

Medical Science, Kerman, Iran

Mohammad Reza Aflatoonian

Bam University of Medical Sciences, Bam, Iran

\section{Corresponding Author:}

Mohammad Reza Aflatoonian

e-mail:mraflatoonian@gmail.com
Submitted / Gönderilme: 18.01.2017

Accepted / Kabul: $\quad 09.03 .2017$

Revised / Düzeltme: 09.03.2017

\section{Introduction}

Toxoplasma gondii is a universal prevalent protozoan parasite which infected all the warm-blooded animals such as humans (1). Human, usually, can be infected via three chief ways of transmission: consumption of tissue cysts in infected meat, consumption of food or water contaminated with oocysts and congenitally $(2,3)$. Toxoplasmosis in immunecompetent persons is seldom symptomatic. However, the disease happening in the fetus or immunocompromised individuals (transplant recipients and patients with acquired immunodeficiency syndrome) might cause serious symptoms or even passing away $(4,5)$. Today, the preferred treatment for toxoplasmosis is combination of pyrimethamine and sulfadiazine. Nevertheless, the use of these drugs is associated with some serious complications including osteoporosis, sepsis and also teratogenic effects (6, 7). Since last centuries, herbal drugs have been considered as the main source for prevention and treatment a broad spectrum of illnesses as well as infectious ones (7). 
Berberis vulgaris L. called in Persian as "Zereshk" (Berberidaceae family) broadly growth in most countries in the world such as Iran (8). In traditional medicine, a variety of portions of $B$. vulgaris such as root, leaf, bark and fruit have been extensively applied for the healing a number of diseases such as skin, respiratory, cardiovascular, digestive, and infectious ones (9). Nowadays, reviews have reported a range of pharmacological possessions of $B$. vulgaris including antinociceptive, antioxidant, anti-inflammatory and antimicrobial effects (10). To the best of our knowledge and according to the literature review, there is no study on the effects of $B$. vulgaris against toxoplasmosis. Therefore, the current investigation aims to evaluate the efficacy of $B$. vulgaris root methanolic extract on infected mice with acute toxoplasmosis.

\section{Materials and methods}

\section{Plant Collection}

The B. vulgaris roots were obtained from the farms in the Baft district of Kerman province, Iran, in May 2016. The identities were confirmed by the botanist at the Botany Department of Shahid Bahonar University, Kerman, Iran. Voucher specimen ( $k f 585)$ of the plant materials was deposited at the Herbarium of Department of Pharmacognosy of the School of Pharmacy, Kerman University of Medical Science, Kerman, Iran.

\section{Preparing of methanolic extract}

Extraction of the dried roots (200 g) of B. vulgaris was performed percolation technique with methanol for $72 \mathrm{~h}$ in room temperature. The extract was moved among filter paper (Whatman No.3, Sigma, Germany) to take out plant remains. The extract was lastly concentrated in vacuum at $50^{\circ} \mathrm{C}$ using a rotary evaporator (Heidolph, Germany) and kept at $-20^{\circ} \mathrm{C}$, until testing (11).

\section{Ethical statements}

This survey was done in line with the recommendations in the Guide for the Care and Use of Laboratory Animals of the National Institutes of Health. The protocol was approved by the Committee on the Ethics of Animal Experiments of the Bam University of Medical Science, Iran (No.218/2017)

\section{Establishment of acute toxoplasmosis}

Forty male NMRI mice (6-8 weeks old) weighing from 20 to $25 \mathrm{~g}$ for establishing animal model of T. gondii were obtained from the Animal House of Kerman University of Medical sciences, Iran. Animals were housed in a colony room with a 12:12 h light/ dark cycle at $21 \pm 2{ }^{\circ} \mathrm{C}$ and were handled according to standard protocols for the use of laboratory animals. They were divided into four groups; every group contained ten mice. Animal model of acute toxoplasmosis was established according to the method described by Asgari et al (2013) using intraperitonealy injection $10^{4}$ tachyzoite of T. gondii, RH strain (12).

\section{Efficacy of B. vulgaris on acute toxoplasmosis}

Mice were divided into four main groups (10 mice per each group) including: (1) non-treated control, (2) mice treated with normal saline for 14 days, (3) orally treated with $B$. vulgaris methanolic extract at the dose of $1 \mathrm{~g} / \mathrm{kg}$ once a day for 14 days, (4) orally treated with $B$. vulgaris methanolic extract at the dose of $2 \mathrm{~g} / \mathrm{kg}$ once a day for 14 days. In $15^{\text {th }}$ day mice in all tested groups were infected T. gondii, $\mathrm{RH}$ strain as mentioned above. The selections of extract doses was based on primary expriments that showed B. vulgaris had no toxicity in mentioned doses. The subsequent factors were performed to determine the efficacy $B$. vulgaris methanolic extract against acute toxoplasmosis in mice model.

\section{Mortality rate}

The mortality rate was determined according to the following formula:

$\mathrm{MR}=\frac{\text { Number of dead mice }}{\text { Number of mice at the beginning of the experiment }} \times 100$

\section{Parasite load}

Counting the mean number of $T$. gondii tachyzoites in the peritoneal fluid of mice. The extracellular tachyzoites in each mouse were counted in 10 high power field (HPF) and then the mean number of tachyzoites $10 / \mathrm{HPF}$ was estimated. Then the mean number of tachyzoites in each group of infected mice was calculated (13).

\section{Statistical analysis}

Data analysis was carried out using SPSS statistical package version 17.0 (SPSS Inc., Chicago, IL, USA). Differences 
between test and control groups were analyzed by $t$-test. In addition, $p<0.05$ was considered statistically significant.

\section{Results}

In the present study we evaluated efficacy of B. vulgaris root methanolic extract against acute toxoplasmosis in mice model. As shown in Figure 1, the mortality rate of infected mice in the control group was $100 \%$ after $5^{\text {th }}$ after establishment. The mortality rate of infected mice in group 3 was $100 \%$, in $9^{\text {th }}$ day after orally administration of $B$. vulgaris at the concentration of $1 \mathrm{~g} / \mathrm{kg}$; indicating that B. vulgaris significantly $(p<0.05)$ increased the time of death in the infected mice. Similarly, the mortality rate of infected mice in group 4 was $100 \%$ in $9^{\text {th }}$ day after orally administration of $B$. vulgaris at the concentration of $2 \mathrm{~g} / \mathrm{kg}$ which demonstrated that $B$. vulgaris significantly $(p<0.05)$ increased the time of death in the infected mice.

Figure 2 indicates the parasite load (mean number of tachyzoites) in tested groups. The mean number of tachyzoites was $131 \times 10^{4}$ and $79 \times 10^{4}$ for infected mice treated with 1 and $2 \mathrm{~g} / \mathrm{kg}$, respectively, whereas in control group the mean number of tachyzoites was $288 \times 10^{4}$ parasite. The obtained results showed that the difference in mortality rate between of $B$. vulgaris at the concentrations of 1 and $2 \mathrm{~g} / \mathrm{kg}$ in comparison to the control group was statistically significant $(p<0.05)$.

\section{Discussion}

At present, there are a restricted number of agents for the treatment of toxoplasmosis and the combination of pyrimethamine and sulfadiazine is the most common (3). However, these drugs may results in some adverse effects, including osteoporosis, sepsis and also teratogenic effects particularly in persons with immunocompromised patients $(2,3)$. So far, efforts to decrease the toxicity of these compounds have been failed, that reinforces the requirement for novel anti-Toxoplasma drugs. Thus, studies that could offer a substitute therapy, condense dosages, treatment time and side effects for toxoplasmosis, would be greeting. Here we evaluated efficacy of $B$. vulgaris root methanolic extract against acute toxoplasmosis induced by RH strain $T$. gondii in mice model.

The obtained results demonstrated that the mortality rate of infected mice was $100 \%$, in $9^{\text {th }}$ day after orally administration of $B$. vulgaris at the concentrations of 1 and $2 \mathrm{~g} / \mathrm{kg}$; indicating that oral administration of $B$. vulgaris for 14 days especially at the aforementioned concentrations had potent prophylactic effects against acute toxoplasmosis in mice and their survival was prolonged to 9 days, while all mice in the control group were death in $5^{\text {th }}$ day. Moreover obtained findings revealed that the mean number of tachyzoites was $131 \times 10^{4}$ and $79 \times 10^{4}$ for infected mice treated with $B$. vulgaris at the concentrations of, respectively, whereas in control group the mean number of tachyzoites was $288 \times 10^{4}$ parasite; which indicated that $B$.

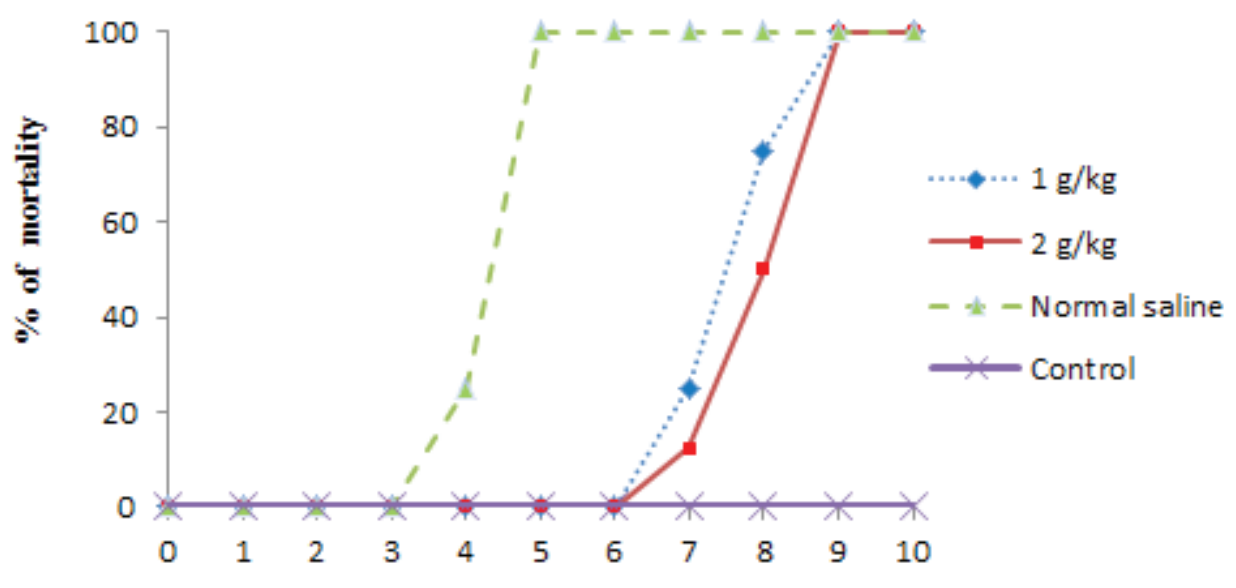

Time (Day)

Figure 1. Effects of orally administration of Berberis vulgaris methanolic root extract on mortality rate of infected mice with acute toxoplasmosis. 


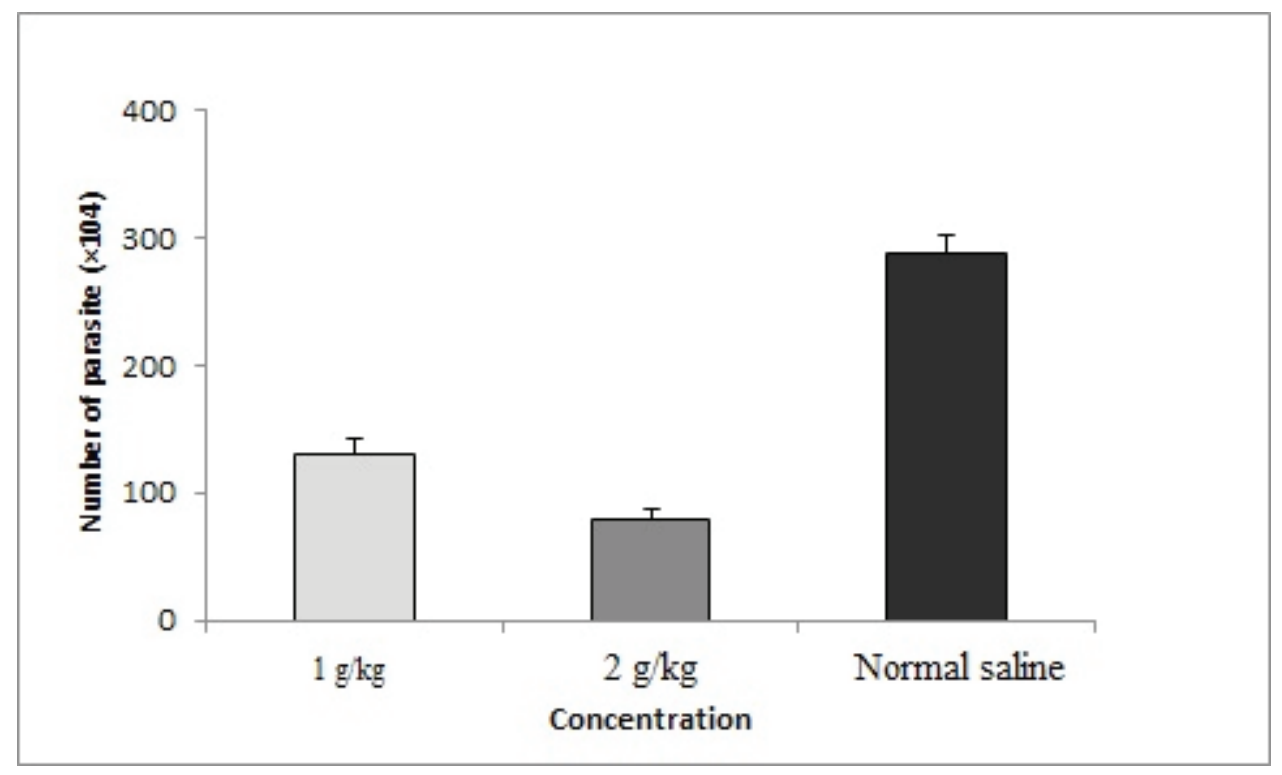

Figure 2. The mean number of T. gondii tachyzoites in the peritoneal fluid of infected mice following orally administration of Berberis vulgaris methanolic root extract

vulgaris significantly reduce parasite load in infected mice with acute toxoplasmosis.

Reviews have reported that the main components of $B$. vulgaris are isoquinoline alkaloids such as berbamine, palmatine, and particularly berberine $(10,14)$. Previous investigations have shown antibacterial, anti candidal, and anti-dermatophyte activity of this plant due to having high amount of isoquinoline alkaloids (15-17). Furthermore, in several study anti-parasitic effects of $B$. vulgaris root extract have been demonstrated; for example in the study conducted by Mahmoudvand et al, it has been proven that $B$. vulgaris methanolic extract and berberine alone have high protoscolicidal effects against protoscoleces of Echinococcus granulosus in low concentration and short exposure time on in vitro model (18). Fata et al (19) have demonstrated that ethanolic extract of $B$. vulgaris considerably reduced ulcer size of cutaneous leishmaniasis of $B A L B / c$ mice after 14 days.

Kaneda et al (20) have demonstrated that berberine notably condensed growth of Entamoeba histolytica, Giardia lamblia, and Trichomonas vaginalis on an in vitro model and result in morphological changes in their structure. Sheng et al (21) showed that, in chloroquine resistant malaria, the combination of berberine and pyrimethamine have a synergistic effect in the removal of parasites and it was further efficient than other drugs including tetracycline or cotrimoxazole. Moreover, Vennerstrom et al (22) have reported that berberine derivatives considerably concealed the parasite load in liver or ulcer size in golden hamsters infected with Leishmania donovani and Leishmania braziliensis when compared with meglumine antimoniate.

Regarding antimicrobial mechanisms of berberine, reviews have demonstrated that antifungal activity of berberine on Candida growth was most likely because of hang-up of both sterol and cell wall biosyntheses in this yeast (8). Moreover, Peng et al (23) reported that berberine can break the structure of bacterial cell wall and restrain synthesis of protein and DNA. With respect to toxicity effects of B. vulgaris and berberine reviews have shown that they are not considered toxic at the doses used in clinical studies, nor have they been revealed to be cytotoxic or mutagenic, whereas, their side effects can be increased to dose development $(5,24,25)$.

\section{Conclusion}

The obtained results delivered the scientific suggestion that natural plants might be used in traditional medicine for the prevention and treatment of parasitic infections such as acute toxoplasmosis. However, additional investigations are needed to assess exact effect of $B$. vulgaris principally its immunomodulatory on acute toxoplasmosis.

\section{Declaration of Interest}

The authors declare that there is no conflict of interest in this study. 
Berberis vulgaris ekstraktının farelerde oluşturulan akut toksoplazmozis üzerine etkileri

ÖZ

Son birkaç yüzyıldır bitkisel kaynaklardan elde edilen ilaçlar çeşitli hastalıklarla birlikte enfeksiyon hastalıklarının da tedavisinde ve profilaksisinde kullanılmaktadır. Bu çalışmada; Berberis vulgaris'in köklerinden hazırlanan matanollü ekstrenin, Toxoplasma gondii RH suşuyla enfekte edilerek akut toksoplazmozis oluşturulmuş farelerdeki etkisi araştırıldı. Erkek NMRI fareleri intraperitoneal yoldan Toxoplasma gondii RH suşuna ait $10^{4}$ taşizoitle enfekte edildikten 24 saat sonra bu farelere oral yoldan Berberis vulgaris'in ekstresi 1 ve 2 g/kg dozlarda, günde $1 \mathrm{kez}, 14$ gün boyunca uygulandı. Tüm farelerde ölüm oranı ve parazit yükü tespit edilerek akut toksoplazmoziste B. vulgaris'in metanollü ekstresinin etkisi belirlendi. Berberis vulgaris'in 1 ve $2 \mathrm{~g} / \mathrm{kg}$ dozlarda oral yoldan uygulanmasının takip eden 9. günde farelerde ölüm oranı $\% 100$ olarak belirlendi, kontrol grubundaki bütün farelerin 5.günün sonunda öldüğ̈ü gözlendi. Berberis vulgaris'in 1 ve $2 \mathrm{~g} / \mathrm{kg}$ dozlarda uygulandığ 1 gruplarda ortalama taşizoit değeri sirasiyla $131 \times 10^{4}$ ve $79 \times 10^{4}$ olarak saptanırken kontrol grubunda taşizoit sayısı ortalama $288 \times 10^{4}$ parazit olarak belirlendi. Elde edilen sonuçlar dikkate alınarak B. vulgaris'in toksoplazmozis profilaksisinde kullanılabilecek bir ilacın üretiminde doğal kaynaklı bir bileşen olarak kullanılabilirliği gösterilmiştir.

Anahtar kelimeler: Toxoplasma gondii; Berberis vulgaris; Profilaksi; In vivo

\section{References}

1. Sukthana Y. Toxoplasmosis: Beyond animals to humans. Trends Parasitol 2006; 22: 137-42.

2. Mahmoudvand H, Sheibani V, Keshavarz H, Shojaee S, Esmaeelpour K, Ziaali N. Acetylcholinesterase inhibitor improves learning and memory impairment induced by Toxoplasma gondii infection. Iran J Parasitol 2016; 11: 177-85.

3. Biesiada G, Kalinowska-Nowak A, Czepiel J, March T. Toxoplasmosis-epidemiology, clinical manifestation and infection in pregnant women. Przegl Lek 2006; 63: 97-9.

4. Mahmoudvand H, Ziaali N, Ghazvini H, Shojaee S, Keshavarz $\mathrm{H}$, Esmaeeilpour K, Sheibani V. Toxoplasma gondii infection promotes neuroinflamation through cytokine networks and induced hyperalgesia in BALB/c mice. Inflamation 2016; 39 : 405-12.

5. Mahmoudvand H, Ziaali N, Aghaei I, Sheibani V, Shojaee S, Keshavarz H, Shabani M. The possible association between Toxoplasma gondii infection and risk of anxiety and cognitive disorders in BALB/c mice. Pathog Glob Health 2015;109:36976.

6. Mahmoudvand $\mathrm{H}$, Sheibani V, Shojaee S, Mirbadie SR, Keshavarz H, Esmaeelpour K, Keyhani AR, Ziaali N. Toxoplasma gondii Infection Potentiates Cognitive Impairments of Alzheimer's Disease in the BALB/c Mice. J Parasitol 2016; 102: 629-35.

7. Tavakoli Kareshk A, Keyhani A, Asadi A, Zia-Ali N, Mahmoudvand H, Mohammadi AR. Seroprevalence of Toxoplasma gondii infection among childbearing age women in Kerman city, southeastern Iran. J Parasit Dis 2016; 40: 15447.

8. Rocha LG, Almeida JR, Macedo RO, Barbosa-Filho JM. A review of natural products with antileishmanial activity. Phytomedicine 2005; 12: 514-35.

9. Zargari A. Medicinal Plants. Tehran University, Tehran 1996.

10. Imanshahidi $H$, Hosseinzadeh $H$. Pharmacological and therapeutic effects of Berberis vulgaris and its active constituent, Berberine. Phytother Res 2008; 22: 999-1012.
11. Mahmoudvand H, Asadi A, Harandi MF, Sharififar F, Jahanbakhsh S, Dezaki ES. In vitro lethal effects of various extracts of Nigella sativa seed on hydatid cyst protoscoleces. Iran J Basic Med Sci 2014; 17:1001-6.

12. Asgari H, Keshavarz H, Shojaee S, Motazedian MH, Mohebali $\mathrm{M}$, Miri R, Mehrabani D, Rezaeian $\mathrm{M}$. In vitro and in vivo potential of RH strain of Toxoplasma gondii (Type I) in tissue cyst forming. Iranian J Parasitol 2013; 8: 367-75.

13. Tavakoli Kareshk A, Keyhani A, Mahmoudvand H, Tavakoli Oliaei R, Asadi A, Andishmand M, Azzizian H, Babaei Z, ZiaAli N. Efficacy of the Bunium persicum (Boiss) essential oil against acute toxoplasmosis in mice model. Iran J Parasitol 2015; 10: 625-31.

14. Ivanovska N, Philipov S. Study of the antiinflammatory action of Berberis vulgaris root extract, alkaloid fractions and pure alkaloids. Int J Immunopharmacol 1996;18: 553-61.

15. Ghaderi R, Maleki Nejad P. evaluation of anticandidal effects of Berberis vulgaris root extracts (methanolic and aqueous) and comparing their effects with those clotrimazole. J Birjand Univ Med Sci 2006; 13: 42-8.

16. Freile ML, Giannini F, Pucci G, Sturniolo A, Rodero L, Pucci O. Antimicrobial activity of aqueous extracts and of berberine isolated from Berberis heterophylla. Fitoterapia 2003; 74: 7025.

17. Mahmoudvand H, Tavakoli Oliaei R, Mirbadie SR, Kheirandish F, Tavakoli Kareshk A, Ezatpour B, Mahmoudvand $\mathrm{H}$. Efficacy and safety of Bunium persicum (boiss) to inactivate protoscoleces during hydatid cyst operations. Surg Infect (Larchmt) 2016;17:713-9.

18. Fata A, Rakhshandeh H, Berenji F, Jalalifard A. Treatment of cutaneous leishmaniasis in murine model by alcoholic extract of Berberis vulgaris. Iran J Parasitol 2006; 1: 39-42.

19. Kaneda Y, Torii M, Tanaka T, Aikawa M. In vitro effects of berberine sulphate on the growth and structure of Entamoeba histolytica, Giardia lamblia and Trichomonas vaginalis. Ann Trop Med Parasitol 1991; 85: 417-25.

20. Mahmoudvand H, Saedi Dezaki E, Sharififar F, Ezatpour B, Jahanbakhsh S, Fasihi Harandi M. Protoscolecidal effect of Berberis vulgaris root extract and its main compound, 
berberine in cystic echinococcosis. Iran J Parasitol 2014; 9:503-10.

21. Sheng WD, Jiddawi MS, Hong XQ, Abdulla SM. Treatment of chloroquine-resistant malaria using pyrimethamine in combination with berberine, tetracycline or cotrimoxazole. East Afr Med J 1997; 74: 283-4.

22. Vennerstrom JL, Lovelace JK, Waits VB, Hanson WL, Klayman DL. Berberine derivatives as anti-leishmanial drugs. Antimicrob Agent Chemother 2005; 34:198-211.

23. Peng L, Kang SH, Yin ZH, Jia R, Song X, Li L, Li Z, Zou Y, Liang
X, Li L, He C, Ye G, Yin L, Shi F, Lv C, Jing B. Antibacterial activity and mechanism of berberine against Streptococcus agalactiae. Int J Clin Exp Pathol 2015; 8: 5217-23.

24. Peychev L. Pharmacological investigation on the cardiovascular effects of Berberis vulgaris on tested animals. Pharmacia 2005; 52: 118-21.

25. Mahmoudvand H, Sharififar F, Sharifi I, Ezatpour B, Fasihi Harandi M, Makki MS, Zia-Ali N, Jahanbakhsh S. In vitro inhibitory effect of Berberis vulgaris (Berberidaceae) and its main component, berberine against different Leishmania species. Iran J Parasitol 2014; 9:28-36. 